\title{
母材打撃ハンマーピーニングによる 溶接継手部の疲労強度向上方法に関する研究
}

\author{
中西 克佳 1 - 森影 康 2 -川畑 篤敬 3 ・鞆 一4 \\ 1正会員 JFEスチール株式会社 土木・建築研究部（†210-0855 神奈川県川崎市川崎区南渡田町1-1） \\ E-mail: kat-nakanishi@jfe-steel.co.jp \\ 2正会員 JFEスチール株式会社 接合・強度研究部（广273-0002 千葉県千葉市川崎町1番地） \\ 3 正会員 JFE エンジニアリング株式会社＼cjkstart橋梁事業部（テ230-8611 神奈川県横浜市鶴見区未広町 2-1） \\ 4正会員 株式会社建設技術研究所 東京本社構造部（广103-8430 東京都中央区日本橋浜町 3-21-1）
}

\begin{abstract}
本稿は, 溶接継手の疲労強度を向上させ, 従来よりも施工の確実性を高めたハンマーピーニングについ ての論文である. 本ハンマーピーニングは, 母材にのみハンマー打撃し, 母材に塑性変形を生じさせるこ とにより, 溶接止端に圧縮残留応力を導入する技術である. 本研究では, 溶接継手疲労試験と有限要素解 析とを行い, これら二つの結果によって, 溶接止端における圧縮残留応力の大きさ, ハンマー打撃による 塑性変形量とその疲労強度, およびそれぞれの相互関係を明確化している. その結果から, 八ンマー打撃 痕形状により, 疲労強度向上を予想する方法を提案した。ささらに, この結果の妥当性を, 実構造を模した 鋼析曲げ疲労試験を行うことにより実証した。
\end{abstract}

Key Words : welded joint, fatigue strength improvement, hammer peening, out-of-plane gusset plate

\section{1. はじめに}

疲労亀裂進展の抑制方法として, ハンマーピーニング (以下，HP）により亀裂に沿って両側に圧縮残留応力 を導入した後，ハンマー打撃により亀裂を閉じる ICR 技術 ${ }^{1}$ が知られている。，一方，鋼構造物溶接部の疲労強 度を向上する方法としては，グラインダー処理や TIG ドレッシング 2)44に代表される溶接止端形状の改善によ り応力集中現象を緩和する方法, 低温変態溶材を付加ビ ードとして用いて溶接止端部に圧縮残留応力を導入する 方法 ${ }^{5}, \mathrm{HP}^{2)}$ 4, や超音波ピーニング が9)により溶接止端 の応力集中現象緩和と溶接止端への圧縮残留応力導入と を同時に行う方法が知られている.ここで，止端形状を 改善する方法については，溶接継手の種類によって異な るものの 1 等級の疲労強度向上が示されている ${ }^{10}$. 著者 らは，後者のうち溶接止端に圧縮残留応力を導入する方 法に着目し，橋梁において主部材として使用される機会 が多く, 疲労上問題となる可能性の高い SM490Y 材の角 回し溶接部を対象に，母材を打撃して溶接止端に圧縮残 留応力を導入するハンマーピーニングによる溶接部の疲 労強度向上効果を検証した．その結果，2 等級以上の疲 労強度向上の可能性が認められたものの, 同じ HP 施工 回数でも HP 施工状態により効果に差異があることが分
かった ${ }^{11)}$.この問題に対処する方法として，計画通りの 圧縮残留応力が導入されているか否かを X 線回折法に より個々に計測する方法が考えられるものの，特殊な装 置が必要であるため高コストであり製造現場での使用に そぐわない，また，HP の管理方法として，打撃による

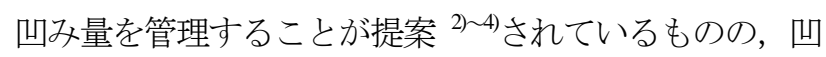
凸のある溶接ビードを含む形状であるため打撃前後の変 化量の計測が困難である。したがって，特殊な装置を用 いることなく, HP 施工後簡単に所定の圧縮残留応力導 入量が確認できる実用可能な疲労強度向上の保証方法の 確立が望まれる.

そこで, 本研究では, 視認できる HP 打撃痕形状に着 目し，HP 打撃痕形状を計測したうえで，HP施工回数を パラメータとした角回し溶接継手疲労試験を実施し, 疲 労強度, 圧縮残留応力, および HP 打撃痕形状の相互関 係から，SM490Y 材かつ公称応力範囲 250MPa 以下にお いて少なくとも疲労強度 2 等級向上を達成する $\mathrm{HP}$ 打撃 痕形状の閾值を明確化した。 また, 溶接止端位置から $\mathrm{HP}$ 打撃痕位置までの距離をパラメータとした同様な溶 接継手疲労試験を実施し, HP 打撃距離に関する十分条 件を明確化した。 これらの試験結果から，HP 打撃痕形 状と HP 打撃距離の両者を用いた母材打撃ハンマーピー ニングによる疲労強度向上保証技術を構築することによ 
り，HP施工の確実性を高めた.

また, 3 次元的な応力場である実構造では HP による 疲労強度向上効果が溶接継手疲労試験結果よりも低下寸 る可能性を鑑み，母材打撃ハンマーピーニング技術にお いても同様な現象が生じるか否かを検証すべく実構造を 模擬した鋼桁曲げ試験を実施した。なお，文献 11)では， 本技術について部分的に報告したが，本論文では，新た な実験結果と考察を加え，全体を再構成している.

\section{2. 溶接継手疲労試験}

\section{(1) 角回し溶接継手疲労試験の概要}

角回し溶接継手試験体の諸元を，図-1(a),(b)に示す. 図-1(b)に示したように，ガセットは，母材の片側のみに 設置した.

使用鋼材は，母材，ガセットともに上降伏点 419 $\mathrm{MPa}$ ，引張強度 $556 \mathrm{MPa}$ ，伸び率 $22.6 \%$, ヤング係数 211,506MPa，およびポアソン比 0.28 の SM490Y である. 母材とガセットとは下向きのすみ肉溶接とし，溶接材料 は JIS Z 3313 YFW-C50DM 1.2mm $\phi ，$ 溶接条件は 100\%CO

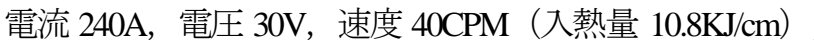
狙い脚長は $6 \mathrm{~mm}$ とした。試験体への HP 施工は，写真-1 および図-2 に示すように，削り出し加工されたエアー 工具先端部を平坦部が $3 \mathrm{~mm} \times 3 \mathrm{~mm}$ ，その縁部が $0.5 \mathrm{~mm}$ の R（丸み）となるように加工し，溶接止端部母材へ垂 直に押し当てながら打撃した．HP 施工速度は $5 \mathrm{~cm} / \mathrm{min}$ 程度，エア一工具の空気圧は $0.63 \mathrm{MPa}$ ，エアー工具が対 象物に与える振動数は $90 \mathrm{~Hz}$ 程度である。また，HP施工 の狙い位置は，エア一工具先端の端部が溶接止端から $1 \mathrm{~mm}$ 以内とした. エアー工具先端を平坦とした理由は， 平坦である方が溶接止端部への圧縮残留応力の導入効率 が高いためである ${ }^{12)}$. 図-2 には HP 施工イメージを，写 真-2 には HP 施工例（施工回数 4 回）をそれぞれ示す. なお，HP 施工時，試験体が曲げ変形しないように，試 験体の長さ方向に母材両端を万力で拘束し，HP 施工後 に取り外したＨP 施工前後で試験体の有意な変形は認 められなかった。

表-1 には，溶接継手疲労試験ケースの内訳を示す. すなわち，疲労試験は，載荷公称応力範囲 100MPa に対 し HP 施工回数 0 回（溶接まま），ならびに載荷公称応 力範囲 150MPa，200MPa，および 250MPa の 3 ケースに 対し HP 施工回数を 0〜4 回とした計 16 ケースに関して 実施した。ここで，全てのケースに対し，最小応力を $3 \mathrm{MPa}$ ，応力比をほぼ 0 とした. HP 施工回数の変動は, 圧縮残留応力導入量の変動を意味しており，圧縮残留応 力の導入量と疲労強度との関係を明確化することを意図 している.

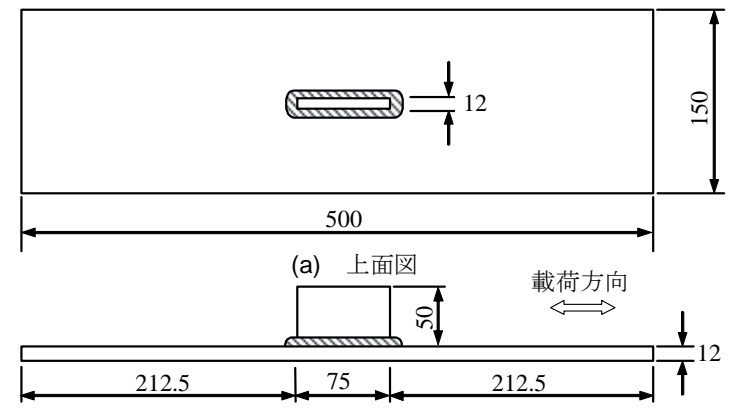

(b) 側面図

図-1＼cjkstart角回し溶接継手試験体の諸元（寸法単位：mm）

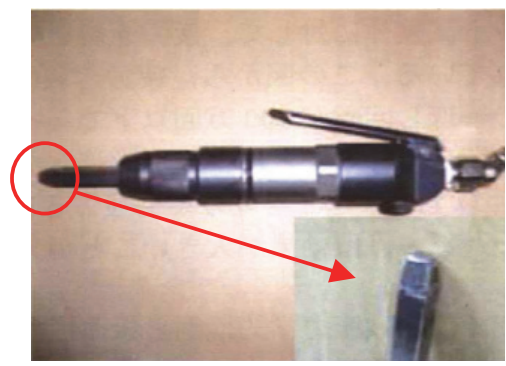

写真-1 エアー工具

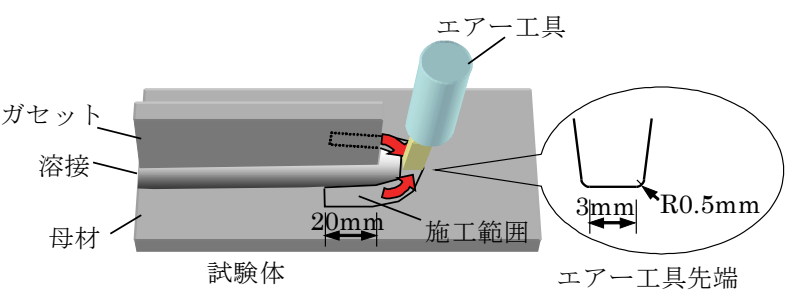

図-2 HP施工イメージ

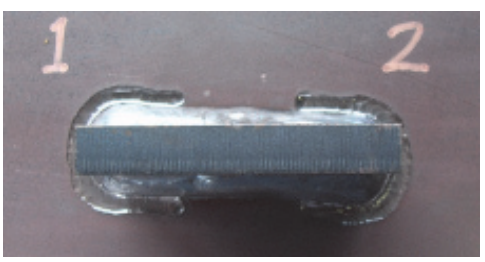

写真-2 HP 施工例（施工回数 4回）

表-1 溶接継手疲労試験ケースの内訳

\begin{tabular}{|c|c|c|c|c|c|c|}
\hline & \multicolumn{5}{|c|}{ HP施工回数 } \\
\hline & & 0回 & 1回 & 2回 & 3回 & 4回 \\
\hline \multirow{4}{*}{$\begin{array}{c}\text { 載荷公称 } \\
\text { 応力範囲 } \\
\Delta \sigma \\
(\mathrm{MPa})\end{array}$} & 100 & 実施 & - & - & - & - \\
\hline & 150 & 実施 & 実施 & 実施 & 実施 & 実施 \\
\hline & 200 & 実施 & 実施 & 実施 & 実施 & 実施 \\
\hline & 250 & 実施 & 実施 & 実施 & 実施 & 実施 \\
\hline
\end{tabular}

\section{(2) 溶接継手疲労試験結果}

図-3 には，各ケースの溶接継手疲労試験結果を，日 本鋼構造協会の疲労強度等級 ${ }^{10)}$ と比較して示す。なお, 図-3 中の右矢印は，疲労亀裂が未発生であるものの時 間短縮のため疲労試験を中断したことを意味している.

図-3 より，HP 施工回数が増加するにつれて，疲労強度 が向上していることが伺える．さらに，溶接ままの試験 体が $\mathrm{E}$ 等級となったことから，少なくとも施工回数 3 回 で疲労強度等級 2 等級向上の C 等級以上となることが分 かる. 


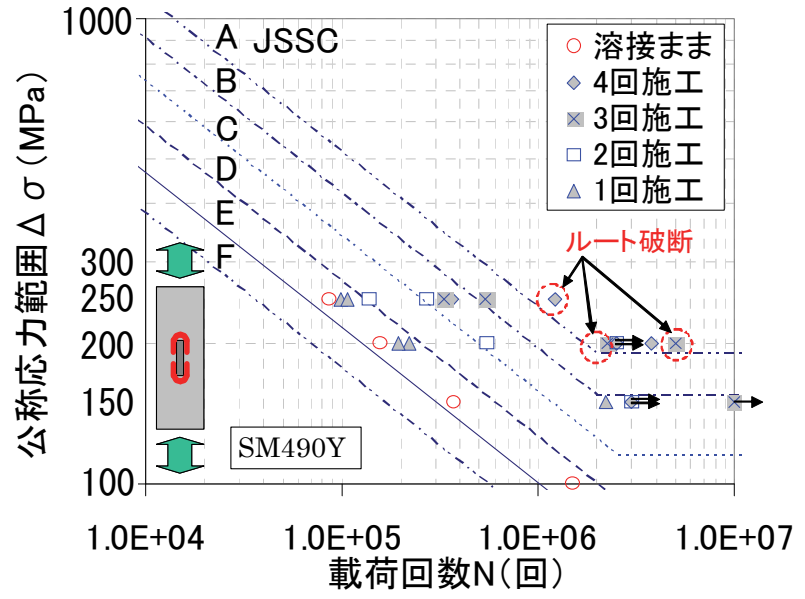

図-3 各ケースの溶接継手疲労試験結果

溶接継手疲労試験に先立ち, 応力集中により疲労亀裂 が発生する可能性が高い面外ガセットの外側の範囲の八 ンマー打撃痕の形状を，レーザー変位計により測定した. また, X 線回折法により $\mathrm{HP}$ 施工後の導入残留応力を計 測した．図-4(a),(b)には窪み面積と残留応力との関係を, 図-5(a),(b)には窪夕面積と載荷公称応力範囲 250MPa 時の 破断回数との関係を，洼み面積を「平均深さ $\times$ 幅」とし た場合と窪み面積を「最大深さメ幅」とした場合とに分 けてそれぞれ示す．ここで，残留応力の測定点を溶接止 端から $10 \mathrm{~mm}$ とした理由は, 溶接止端に打撃痕が近接し ており残留応力の測定が困難なため, かつハンマー打撃 による残留応力分布が打撃痕の溶接止端側と打撃痕の母 材側とで類似すると考えたためである.

図-4(a),(b)より, 窪み面積の増加に伴い, 圧縮残留応 力の導入量が増加していることが分かる. 図-4(a),(b)の 導入残留応力が降伏值を若干超えているのは, 面内方向 の拘束効果によるものと考えられる．また，図-5(a),(b) より, 窪み面積の増加に伴い, 破断に要する載荷回数が 増えていることが分かる. これらのことから, 導入残留 応力はハンマー打撃痕の等み面積で関連付けることがで き，かつ導入圧縮残留応力寸なわち窪み面積が大きいほ ど疲労強度が向上寸ると言える.また, 図-3 の考察で 述べたように, SM490Y 材において疲労強度等級 2 等級 向上の $\mathrm{C}$ 等級を超えるためには，ハンマー打撃痕の 「平均深さ $\times$ 幅」が $0.7 \mathrm{~mm}^{2}$ 以上，あるいは「最大深さ メ幅」が $1 \mathrm{~mm}^{2}$ 以上あれば良いと言える。 なお，図-5(b) において C 等級を超えた試験体は，最大深さが $0.22 \mathrm{~mm}$ 以上，幅が $3.5 \mathrm{~mm}$ 以上であった。窪み面積を，「平均 深さ×幅」および「最大深さ×幅」の 2 種類で整理した のは，本来の窪み面積は「平均深さ×幅」であるが,

「最大深さ×幅」で整理することにより，計測の簡略化 （例えば，後者は溶接ゲージとノギスで計測）に繋げる ことを意図している.

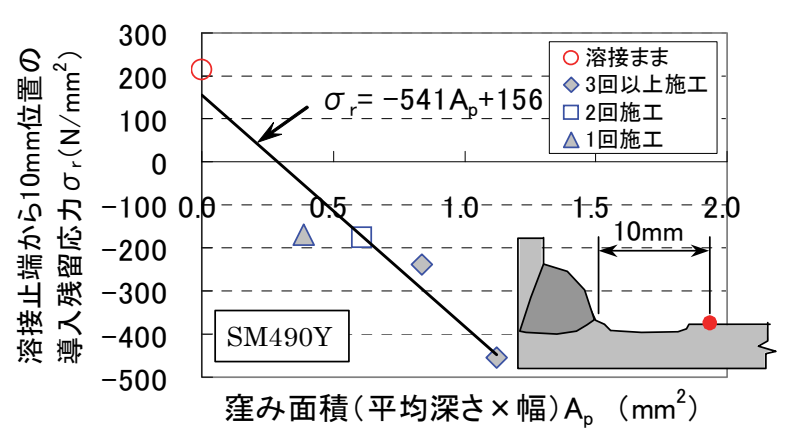

（a）窪み面積を「平均深さX幅」とした場合

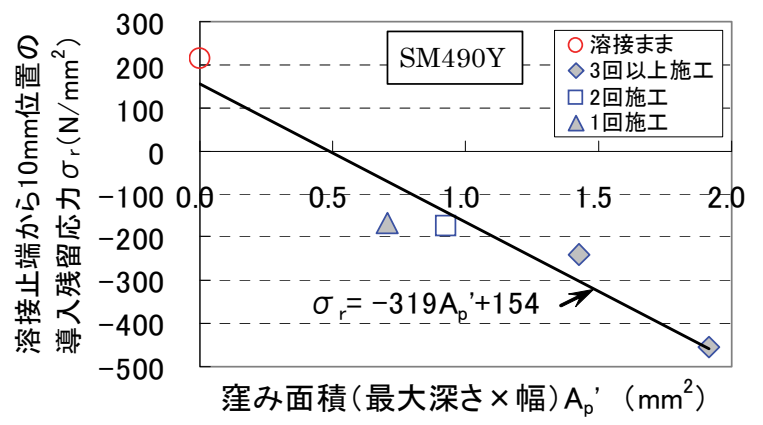

(b) 窪み面積を「最大深さX幅」とした場合

図-4 崔み面積と導入残留応力との関係

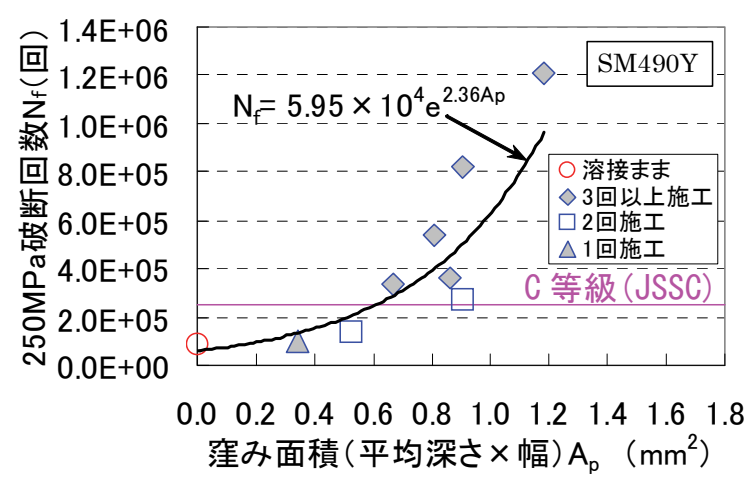

（a）窪み面積を「平均深さX幅」とした場合

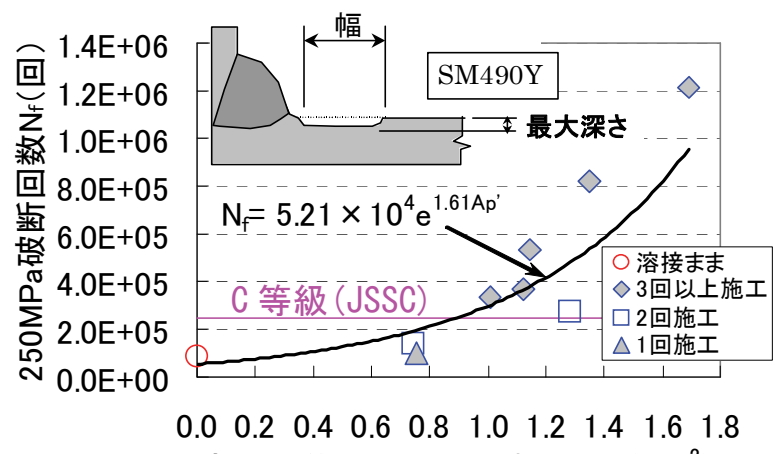

窪み面積 (最大深さ $\times$ 幅) $A_{p}{ }^{\prime} \quad\left(\mathrm{mm}^{2}\right)$

（b）嵀み面積を「最大深さX幅」とした場合

図-5 寉み面積と 250MPa破断回数との関係

(3) 溶接止端からの打撃距離

溶接止端への圧縮残留応力導入量のパラメータとして, 上述した打撃痕の窪み面積以外に, 溶接止端からの打撃 
距離が挙げられる. 打撃による塑性流動により面内方向 に圧縮残留応力が導入されるため，打撃位置を溶接止端 から離し過ぎると効果は減少すると考えられる. また, 十字溶接継手等に適用寸る場合のHP施工は直線施工と なるため, 自動溶接機と同様に自動でHP施工寸る方法 が考えられる ${ }^{13)}$ ，ところが，溶接線は必ずしも直線でな いためHP施工を溶接線に沿って蛇行施工することにな り，HP施工の自動化は困難である.HP施工の自動化を 可能とするためには，溶接止端から打撃ピン端部までの 距離に許容範囲を設定する必要がある。 そこで, 所定の 疲労強度が得られる溶接止端からの打撃距離の許容範囲 を見出すために，図-6に示すように，溶接止端からの打 撃距離を $0 \mathrm{~mm}$ から $5 \mathrm{~mm}$ まで $1 \mathrm{~mm}$ 毎に変化させて同様な窪 み面積のHP施工（施工回数4回）を行った6体の角回し 溶接継手試験体に対し，公称応力範囲250MPa（最小応 力3MPa）の同様な溶接継手疲労試験を実施した. 図-7 には，打撃距離と疲労強度との関係を示す．写真-3(a) (f)には，溶接止端からの距離をパラメータにした試験体 のHP処理面の様子を示寸.

図-7より, 疲労強度は溶接止端から打撃痕端部までの 距離が $1 \mathrm{~mm}$ のき最も大きく, $1 \mathrm{~mm}$ から $2 \mathrm{~mm}$ の間で急激 に低下し，2mm以上のとき疲労強度等級がC等級に満た なくなることが分かる．したがって，目標の2等級向上 を保証するための打撃痕位置の閾值は，溶接止端位置か ら1mmから2mmの間にあると言える。

以上のことから，SM490Y材において疲労強度等級2等 級向上のC等級を超えるためには, ハンマー打撃痕の窪 み面積（「最大深さ $\times$ 幅」で定義）が $1 \mathrm{~mm}^{2}$ 以上かつ溶 接止端位置からHP打撃痕端までの距離 $1 \mathrm{~mm}$ 以内が十分 条件と言える. 図-8には，この十分条件を満たす溶接継 手疲労試験結果を溶接ままの疲労試験結果と比較して示 すことにより，母材打撃ハンマーピーニングによる疲労 強度向上効果を示寸.

\section{3. 溶接止端への圧縮残留応力導入原理}

\section{（1） 残留応力導入原理}

平坦な金属表面に等分布の圧力が与えられた時，図-9 に示寸ように, 圧力部近傍には面内方向の主応力が発生 することが知られている ${ }^{12}$ ．金属の降伏值以上の圧力が 作用すると，塑性流動が生じるため圧力部が窪む.この 塑性変形が圧力によって発生した主応力を金属の中で拘 束寸るため, 発生応力は圧縮残留応力として保持される. この圧縮残留応力は, 図-4(a),(b)より, 塑性流動が生じ た分だけ，概ね降伏值を限度に増加する．保持される圧 縮残留応力量は, 圧力部が一方向に無限長である場合, 式(1)に示すように，無限長に対し直角面の窪み面積の

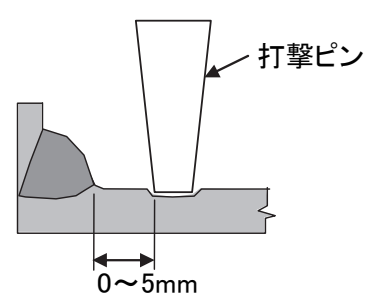

図-6 溶接止端からの打撃距離

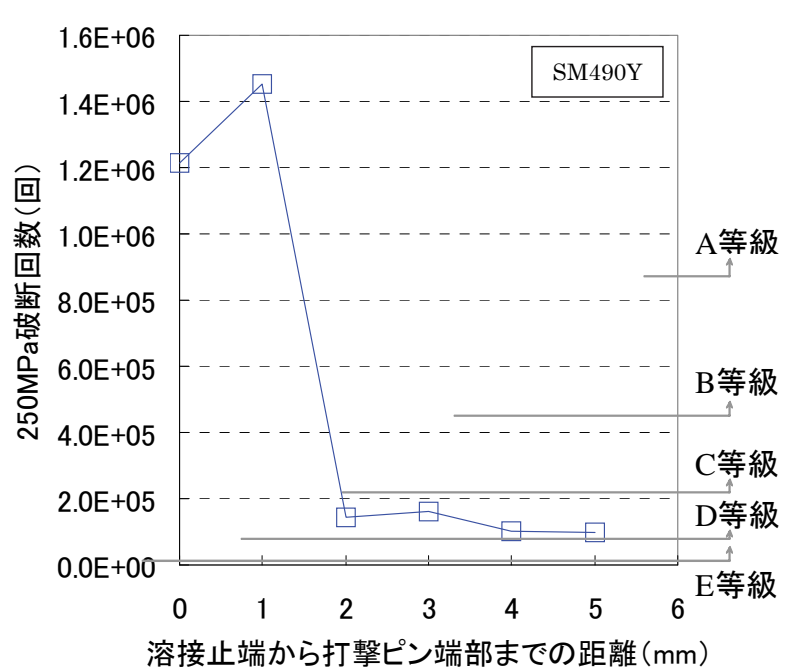

図-7 打撃距離と疲労強度との関係

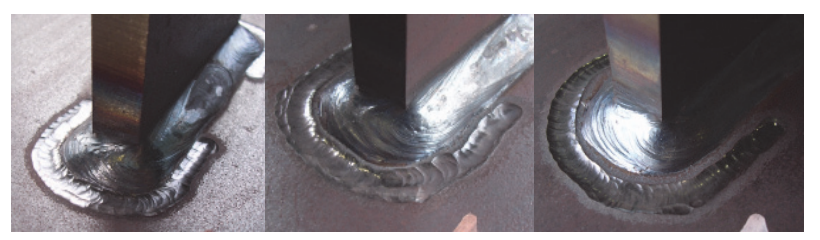

$\begin{array}{lll}\text { (a) 打撃距離 } 0 \mathrm{~mm} & \text { (b) 打撃距離 } 1 \mathrm{~mm} \quad \text { (c) 打撃距離 } 2 \mathrm{~mm}\end{array}$

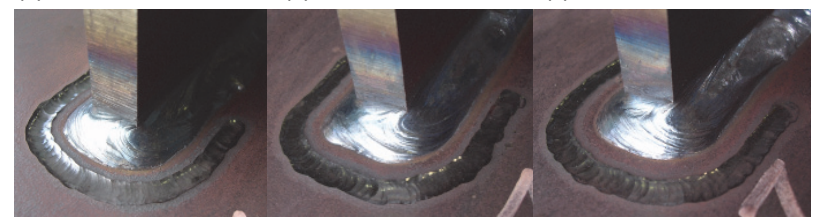

(d) 打撃距離3mm (e) 打撃距離 $4 \mathrm{~mm}$ (f) 打撃距離 $5 \mathrm{~mm}$

写真-3 溶接止端からの打撃距離をパラメータにした試験体の $\mathrm{HP}$ 処理面の様子

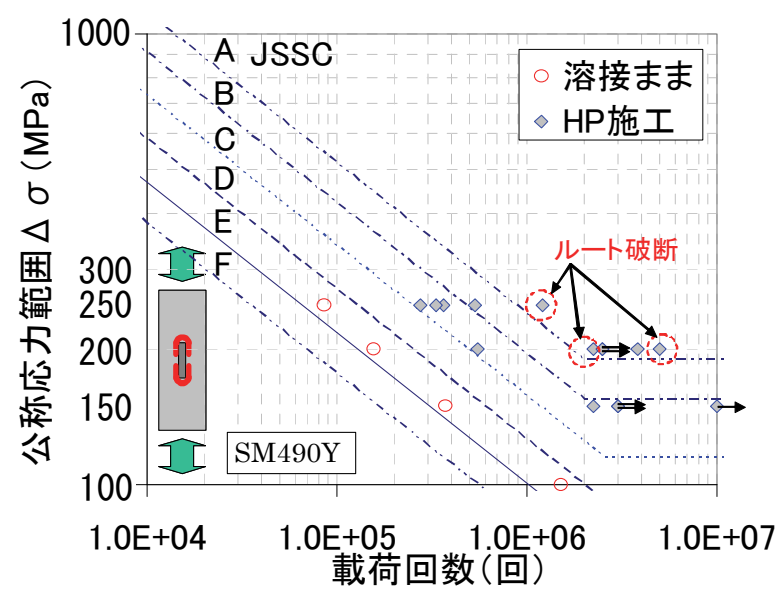

図-8母材 HP 施工による疲労強度向上効果 
関数で表すことができる.

$$
\sigma_{r}=f\left(A_{p}\right)
$$

ここに, $\sigma_{r}$ : 圧縮残留応力, $A_{p}$ : 窪み面積

なお，圧力部が溶接部等のように剛性が高い部分の近 傍の場合，その岡性が主応力に抵抗するため拘束力が向 上し, 圧縮残留応力はより効率的に導入されると考えら れる.

\section{（2）有限要素解析による残留応力導入量検証}

母材打撃ハンマーピーニングによる溶接止端への圧縮 残留応力導入メカニズムについて検証するため, 図-1に 示した角回し溶接継手試験体を対象に有限要素解析を実 施した. 解析モデルは3次元2軸対象モデルとし, 有限要 素ソルバーとしてはABAQUS ver.6.7を用い，接触要素を 介して塑性変形させる大変形解析を実施した．図-10に は有限要素解析モデルを, 図-11には解析に用いた母材

（SM490Y材）および溶接金属の応力ーひずみ関係を示 す.

打撃ピンは剛体とし，打撃ピンの端面と溶接止端との 距離は $0 \mathrm{~mm}$ とした．HP施工前には，溶接後の溶接止端 近傍における引張残留応力を模擬寸るため, 溶接金属に 1,500 $\mathrm{C}$ の昇温一冷却による熱ひずみを与えた。ここで, 鋼材の線膨張係数は， $10 \times 10^{-6} \% \mathrm{C}$ とした。 また， HP 施 工による打撃痕の形成を再現するため, 実験で用いた先 端形状と同形状の打撃ピンを母材側表層から $0.2 \mathrm{~mm}$ ま で 静的に押し込んだ後に引き抜いた．試験体長手方向 のみに負荷を与える 1 軸載荷の解析であることを考慮し， 打撃ピンの押込み一引抜きは 1 点のみとした. また，打 撃ピンの押込み一引抜き時には，2.(1)に示した HP 施工 条件に合わせ，試験体母材の曲げを拘束し，長手方向に 伸縮自由の境界条件を与えた. その結果，打撃ピンを押 し込んで引き抜いた後の打撃痕の深さは $0.198 \mathrm{~mm}$, 溶接 止端から打撃痕端部までの距離は約 $0.3 \mathrm{~mm}$ となった. この打撃ピン押込み一引抜き時点, さらに試験体軸方向 （X 方向）に 150MPa および 250MPa の引張応力を付与 した時点，それぞれの溶接止端近傍の応力分布を調べた。

\section{(3) 解析結果とその考察}

3次元有限要素解析によるHP施工前後の溶接止端近傍 の残留応力分布計算結果を, 打撃痕近傍におけるX線回 折による残留応力測定結果と比較して図-12に示寸. 残 留応力測定に供した試験体の平均打撃痕深さは $0.221 \mathrm{~mm}$ であった．図-12より，HP施工前において溶接止端近傍 に導入された引張側の残留応力が，HP施工後において ほぼ圧縮側に転じていることが分かる．特に，HP施工 により押し出された打撃痕の外側において大きな圧縮残 留応力が発生している. 例えば, 溶接止端位置において,

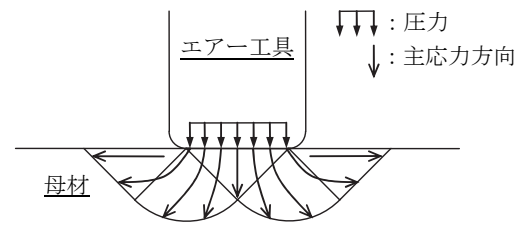

図-9＼cjkstart圧力を受ける平坦な金属表面の主応力方向

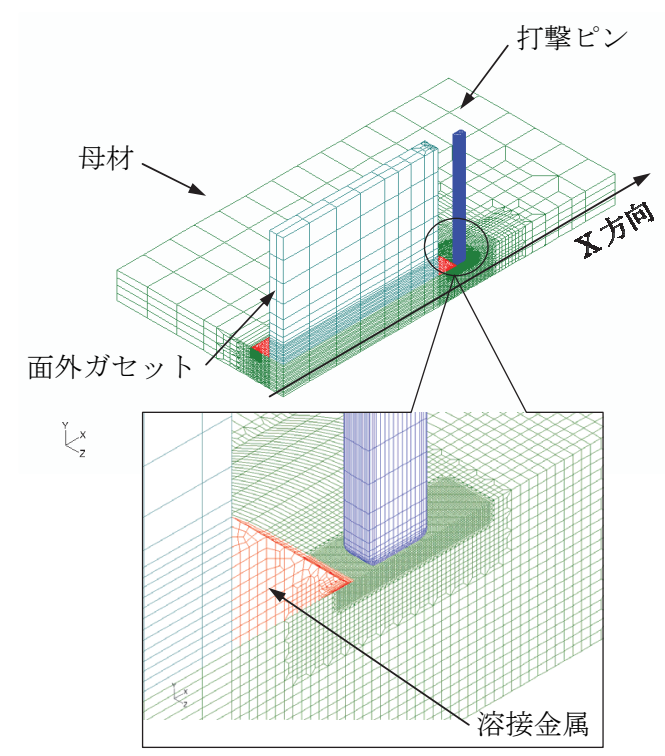

図-10 有限要素解析モデル

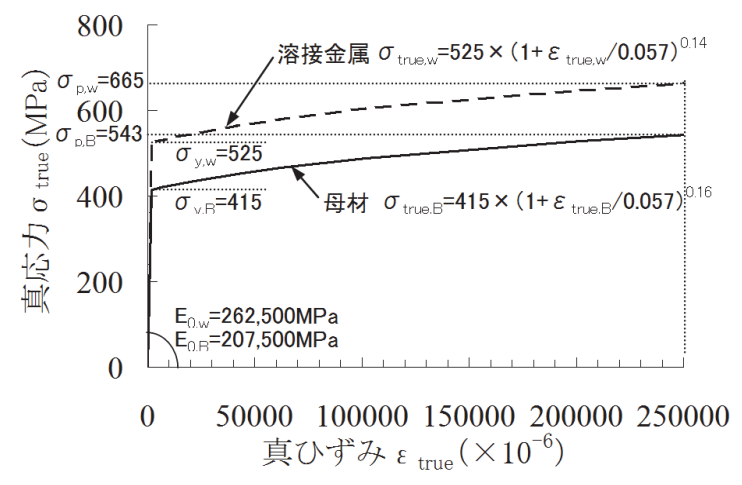

図-11 母材および容接金属の応力ーひずみ関係（解析）

$\mathrm{HP}$ 施工前の引張応力約480MPaが， $\mathrm{HP}$ 施工後に-329MPa の圧縮応力となっている．また，HP施工後の残留応力 分布に関し解析結果と測定結果とを比較すると，両者は 近似していることが分かる.ささらに，圧縮残留応力のピ 一クは，打撃痕より $1 \mathrm{~mm}$ 程度離れた位置に存在している ことが分かる.これらのことから，打撃ピンで母材側を 押し込んだ後，引き抜いて打撃痕を形成することによっ て, 溶接止端に圧縮残留応力が付与されることが解析的 にも検証できた.

つぎに，打撃ピン押込み一引抜き後，さらに公称 $150 \mathrm{MPa} の \mathrm{X}$ 方向引張付与時, および公称 $250 \mathrm{MPa} の \mathrm{X}$ 方向 引張付与時の溶接止端の忘力を, 溶接ままの場合と HP 施工の場合とを比較して図-13に示寸. 図-13より, HP施 工の場合, 溶接止端の圧縮応力-329MPaが公称 $150 \mathrm{MPa}$ の 


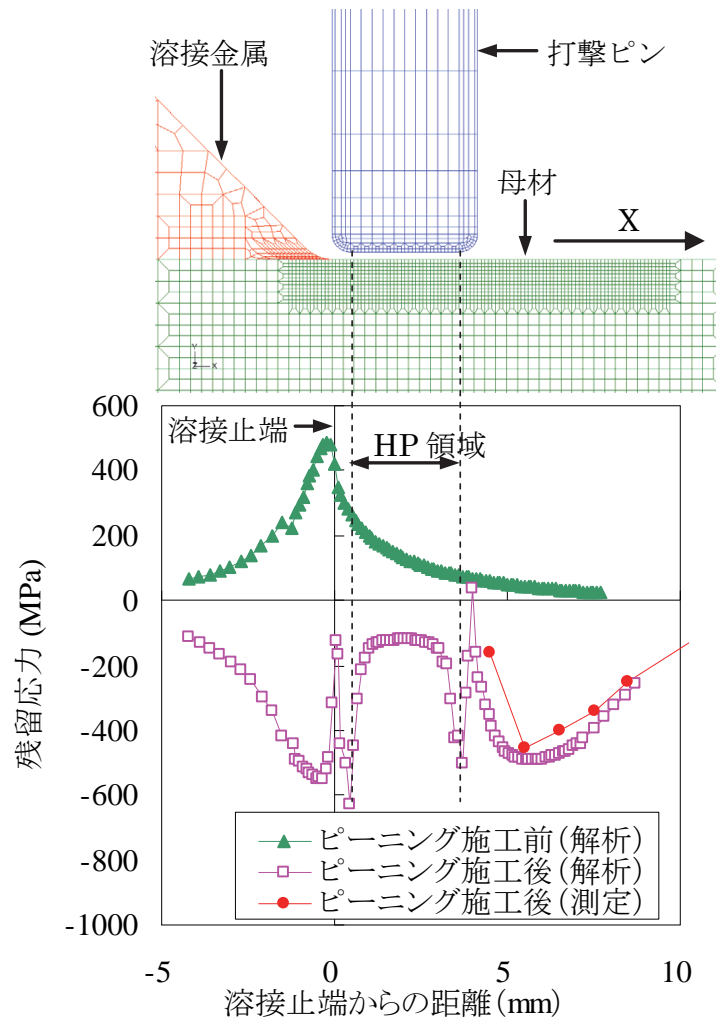

図-12 HP 施工前後の溶接始端近傍の X 方向残留応力分布

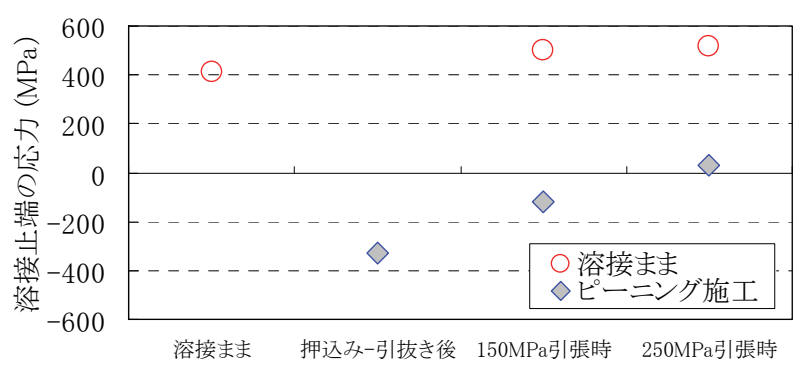

図-13 HP 施工後の引張時における溶接止端応力

X 方向引張付与を施した後においても-120MPa の圧縮応 力, 公称 $250 \mathrm{MPa}$ の $\mathrm{X}$ 方向引張付与を施した後において も溶接ままに比べて非常に小さく $32 \mathrm{MPa}$ の引張灾力と なっていることが分かる．なお， $-329 \mathrm{MPa}+250 \mathrm{MPa}=$ -79MPa とならないのは応力集中現象によるものであり, 応力集中係数が 1.5 以下と小さいのは，止端近傍におけ る打撃痕の存在により溶接止端への応力集中が緩和さ れるためと考えられる. 寸なわち, 溶接止端近傍の母 材側への HP 施工により, 溶接止端に大きな圧縮残留応 力を導入でき，かつ母材に存在する止端の応力集中を 溶接金属の形状を変化させずに緩和することによって 溶接継手の疲労強度向上が可能となる.

以上の解析結果から, HP 施工により, 溶接止端の引 張残留応力を圧縮残留応力に変え, SM490Y 材の場合, 公称 $250 \mathrm{MPa}$ の X方向引張応力を作用させて初めて引張 応力状態となることが判明した。

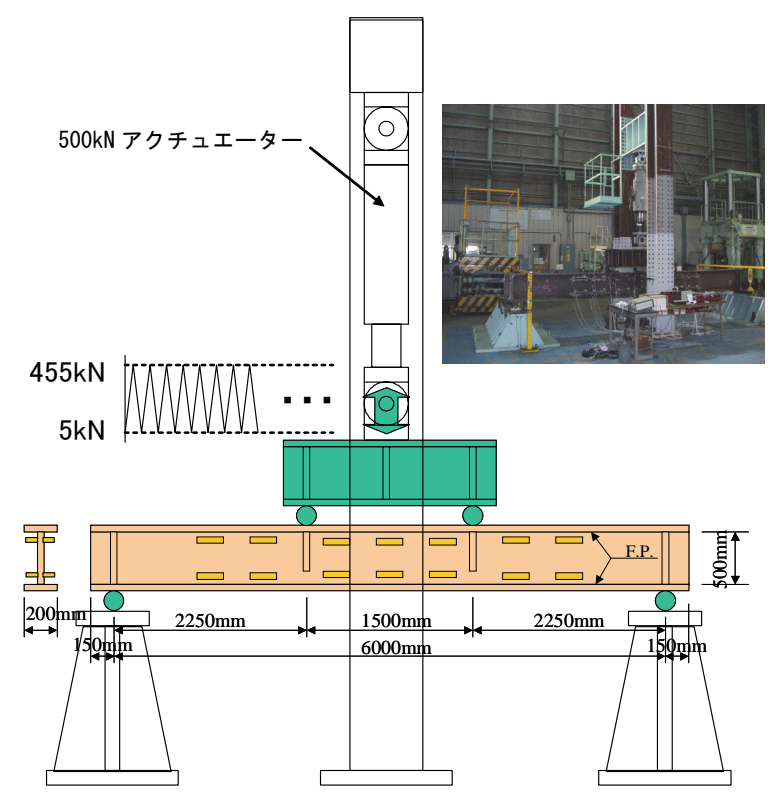

図-14 鋼析曲げ疲労試験概要

\section{4. 実構造模擬疲労試験}

\section{(1) 鋼椼曲げ疲労試験の概要}

実機相当の 3 次元的な応力場での母材打撃ハンマーピ ーニングによる疲労強度向上効果を検証するため, 複数 の角回し溶接部を有する鋼析の 4 点曲げ疲労試験を実施 した．図-14 には鋼析曲げ疲労試験概要を示す．図-14 に示寸ように，試験体には複数の水平補剛材を設置して おり, 水平補剛材の角回し溶接部（試験箇所）から疲労 亀裂が発生する載荷回数が溶接継手疲労試験で確認した 疲労強度 2 等級向上を満足しているか否かを確認寸る.

荷重範囲は $450 \mathrm{kN}$ （最小 $5 \mathrm{kN}$ ，最大 $455 \mathrm{kN}$ ）とし，載 荷回数は疲労強度 2 等級向上を達成するまで，あるいは 試験が続行不可能になるまで実施した。ここで，荷重範 囲 450kNにより，試験体軸方向が最大曲げモーメント作 用位置かつ断面高さ方向が水平補剛材位置において，試 験体軸方向に公称 $123 \mathrm{MPa}$ の応力が発生する. 試験体の 健全性を確認寸るため, 1 回, 100 回，1,000 回，1 万回， 10 万回，20 万回，以降少なくとも 20 万回毎に 1 サイク ルの静的繰返し載荷試験を実施し，たわみ及びひずみの 変化を確認した. 疲労亀裂が発生し亀裂長が $20 \mathrm{~mm}$ に達 した時には，亀裂部および亀裂先端延長 $10 \mathrm{~mm}$ を ICR 処 理 ${ }^{1)}$ により補修した。 また，疲労亀裂がさらに進展した 場合には，亀裂先端にストップホールを開けた．下フラ ンジに疲労亀裂が発生した場合には，下フランジ断面相 当の添接板を用いた高力ボルト摩擦接合により補修した. なお，補修により応力が緩和され，所定の公称応力を下 回った試験箇所は，その後の載荷回数を結果整理の際に 加算しないこととした. 


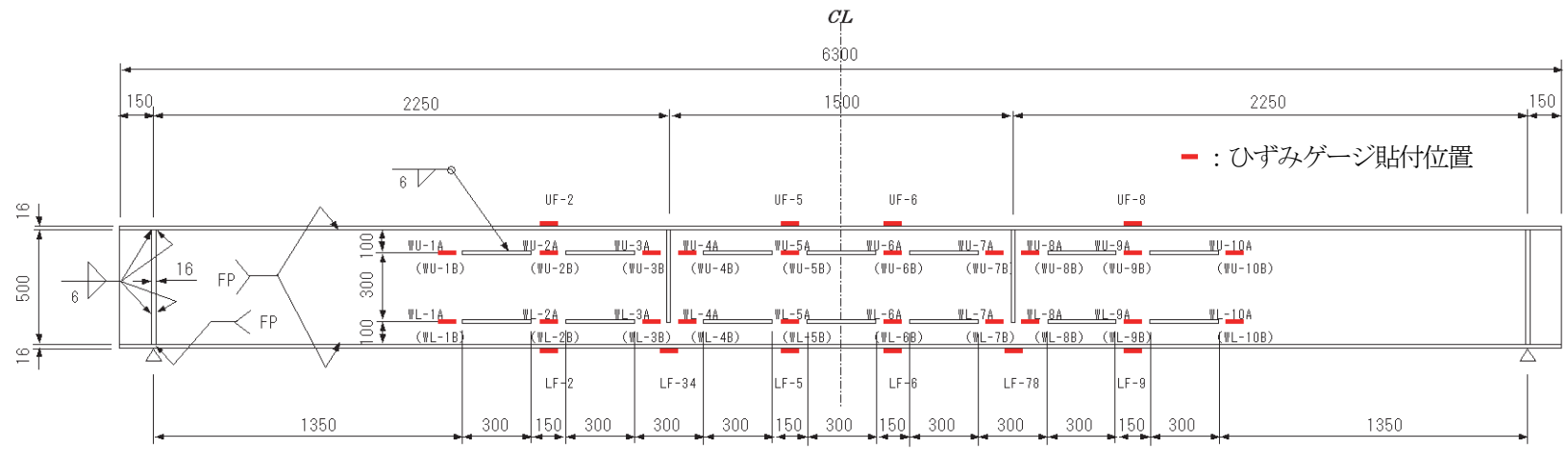

図-15 鋼析曲げ疲労試験体の一般図（寸法単位：mm）

表-2 使用鋼材の機械的性質

\begin{tabular}{|c|c|c|c|c|c|}
\hline $\begin{array}{c}\text { 板厚 } \\
(\mathrm{mm})\end{array}$ & $\begin{array}{c}\text { 降伏強度 } \\
(\mathrm{MPa})\end{array}$ & $\begin{array}{c}\text { 引張強度 } \\
(\mathrm{MPa})\end{array}$ & $\begin{array}{c}\text { 伸び率 } \\
(\%)\end{array}$ & $\begin{array}{c}\text { ヤング係 } \\
\text { 数(MPa) }\end{array}$ & $\begin{array}{c}\text { ポアソ } \\
\text { ン比 }\end{array}$ \\
\hline 12 & 419 & 556 & 22.6 & 211,506 & 0.28 \\
\hline 16 & 413 & 550 & 26.6 & 214,017 & 0.28 \\
\hline
\end{tabular}
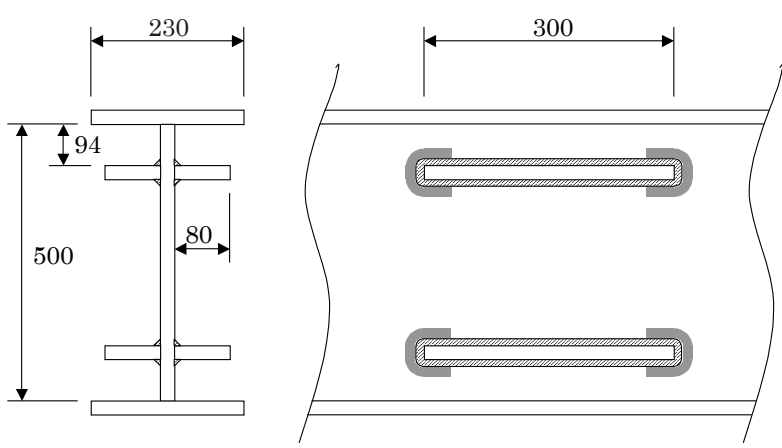

図-16 水平補剛材角回し溶接部への HP 施工 (寸法単位 : mm)

\section{（2）鋼椼曲げ疲労試験体}

鋼析曲げ疲労試験体は，SM490YA 材の I 形断面（ウ ェブ高さ $500 \mathrm{~mm}$ ， ウェブ厚 $12 \mathrm{~mm}$ ，上下フランジ幅 $230 \mathrm{~mm}$ ，上下フランジ厚 $16 \mathrm{~mm}$ ） で支間長 $6,000 \mathrm{~mm}$ とし た ${ }^{14)}$. 載荷点および支点には，板厚 $12 \mathrm{~mm}$ および $16 \mathrm{~mm}$ の垂直補岡材を各 2 力所計 4 力所のウェブ両面に設置し た. 水平補岡材 $($ PL. $80 \times 12 \times 300$, SM490YA材) は, 上 下フランジから $100 \mathrm{~mm}$ 離した位置のウェブ両面 28 カ所 に設置した. ここに，試験体を構成する全ての部材は長 さ方向を圧延方向とし，ウェブとフランジとはレ形開先 の完全溶込み溶接とした．表-2 には，使用鋼材の機械 的性質を示す.

ウェブと水平補剛材とはウェブを水平にして下向きの すみ肉溶接とし，溶接条件は，JIS Z 3313 YFW-C50DM $1.2 \mathrm{~mm} \phi, 100 \% \mathrm{CO}_{2}$, 電流 $240 \mathrm{~A}$ ，電圧 $30 \mathrm{~V}$ ，および速度 $40 \mathrm{CPM}$ (入熱量 $10.8 \mathrm{KJ} / \mathrm{cm}$ ) とした. 狙い脚長を $6 \mathrm{~mm}$ と し，角回し部が溶接始端・終端とならないように配慮し た. 鋼桁曲げ疲労試験体の一般図を図-15 に示す.なお, 図-15 に付記しているように，角回し溶接部近傍（各水 平補岡材端部から $75 \mathrm{~mm}$ の位置) には，試験体の健全性 を確認するため，試験体軸方向に一軸ひずみゲージを貼

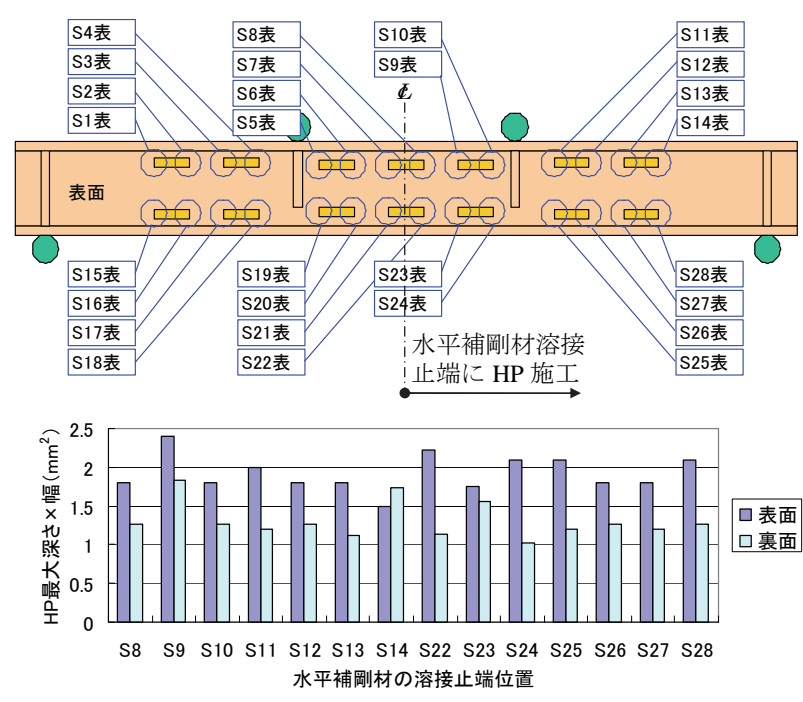

図-17 試験体 1体目の各角回し溶接部の HP 施工形状

付した.

試験体は 2 体とし， 1 体目は，試験体中央から試験体 軸方向片側半分のウェブ両側の水平補岡材角回し溶接止 端近傍 28 箇所（試験箇所）に，図-16 に示すように, $\mathrm{HP}$ 施工を行った. 試験体中央から試験体軸方向もう片 側半分のウェブ両側の水平補剛材角回し溶接止端は，比 較のため，HP施工せずに溶接ままとした。

$\mathrm{HP}$ 施工後，ノギスによる HP 施工幅計測と溶接兮一 ジによる HP 最大深さ計測を行った。計測の結果，以下 の条件を満足しない場合は，条件を満足するまで追加 HP施工を行った.

条件 $1: \mathrm{HP}$ 窪みの最大深さ $>0.22 \mathrm{~mm}$

条件 $2: \mathrm{HP}$ 窪みの幅 $>3.5 \mathrm{~mm}$

条件 $3: \mathrm{HP}$ 窪みの最大深さ $\times$ 幅 $>1 \mathrm{~mm}^{2}$

条件 $4: \mathrm{HP}$ 窪み端部と溶接部との距離 : 0 1mm

図-17 には，試験体 1 体目の各角回し溶接部の HP 施 工形状計測結果を，HP 施工位置図と併せて示す. 図-17 より, 全ての HP 施工箇所でハンマー打撃痕の窪み面積 (最大深さ $\times$ 幅) が $1 \mathrm{~mm}^{2}$ 以上を満たしていることが分 かる.

試験体 2 体目は，試験体軸方向中央で HP 施工管理レ 
ベルを変えた. すなわち，試験体軸方向中央から片側半 分を $\mathrm{HP}$ 窪み形状で管理（試験体 1 体目と同じ施工管理 レベル）とし，もう片側半分を窪み形状を管理しない $\mathrm{HP}$ 施工回数管理（施工回数 2 回）とした. 図-18には, 試験体 2 体目の各角回し溶接部の HP 施工形状計測結果 を，HP 施工位置図と併せて示す．図-18より，HP 施工 回数 2 回の場合は, ハンマー打撃痕の窪み面積（最大深 さ×幅）が $1 \mathrm{~mm}^{2}$ 以上を満たしていない箇所があること が分かる.

表-3 には，曲げ疲労試験により各試験箇所に発生す る公称作用応力範囲と式(2)により求めた各試験箇所が 各疲労等級を達成する載荷回数を示す ${ }^{10}$.

$$
N=2,000,000 \times{ }^{\Delta \sigma_{f}{ }^{3}} / \Delta \sigma^{3}
$$

ここに, $\Delta \sigma_{f}$ は 2,000,000 回基本応力範囲（MPa）であり， $\mathrm{E}$ 等級のとき $80 \mathrm{MPa} ， \mathrm{D}$ 等級のとき $100 \mathrm{MPa}, \mathrm{C}$ 等級のと き $125 \mathrm{MPa}$ である.また, $\Delta \sigma$ は公称作用応力範囲 (MPa) である.

\section{(3) 鋼椼曲げ疲労試験結果}

試験体 1 体目は，載荷回数 260 万回で溶接まま側に多 数の亀裂が発生・進展し, 試験続行不可能となったため 試験を終了した. 試験終了時の水平補剛材溶接部の亀裂 発生状況および載荷回数と公称応力範囲との関係を, 図 -19 に示す。ここで, 図中の亀裂発生のプロットは, 磁 粉探傷により疲労亀裂を確認した時の載荷回数である.

載荷回数 62 万回で溶接止端番号 S4 7 および S18〜21 から疲労亀裂が発生し，その後 67 万回で S1，73 万回で S15 から疲労亀裂が発生した.いずれも溶接ままの箇所 であり, HP 施工位置からは疲労亀裂が発生していない. にもかかわらず図-19 上の HP 施工した試験箇所全てが 260 万回のプロットとなっていないのは，試験体軸方向 中央より HP 施工側にも，ウェブと下フランジとの溶接 部に疲労亀裂が発生し，下フランジ破断一の対処として 添接板補修を施したことにより，ひずみが緩和された箇 所があるためである，すなわち，前述したように，ひず み緩和後の載荷回数を加算しなかったことによる.

図-19 より，少なくとも，公称応力範囲 123MPa の角 回し溶接止端（圧縮側）において，疲労強度等級が溶接 まま部の $\mathrm{E}$ 等級に対して HP 施工部は少なくとも 2 等級 向上の C 等級以上，および公称応力範囲 $115 \mathrm{MPa}$ の角回 し溶接止端（引張側，圧縮側）において, 疲労強度等級 が溶接まま部の $\mathrm{F}$ 等級に対して HP 施工部は少なくとも 2 等級向上の D 等級以上であることが分かる.また，公 称応力範囲が 74MPa の角回し溶接止端においても, 溶 接まま部に対して HP 施工部は疲労強度等級が少なくと も 1 等級以上向上していることが分かる.
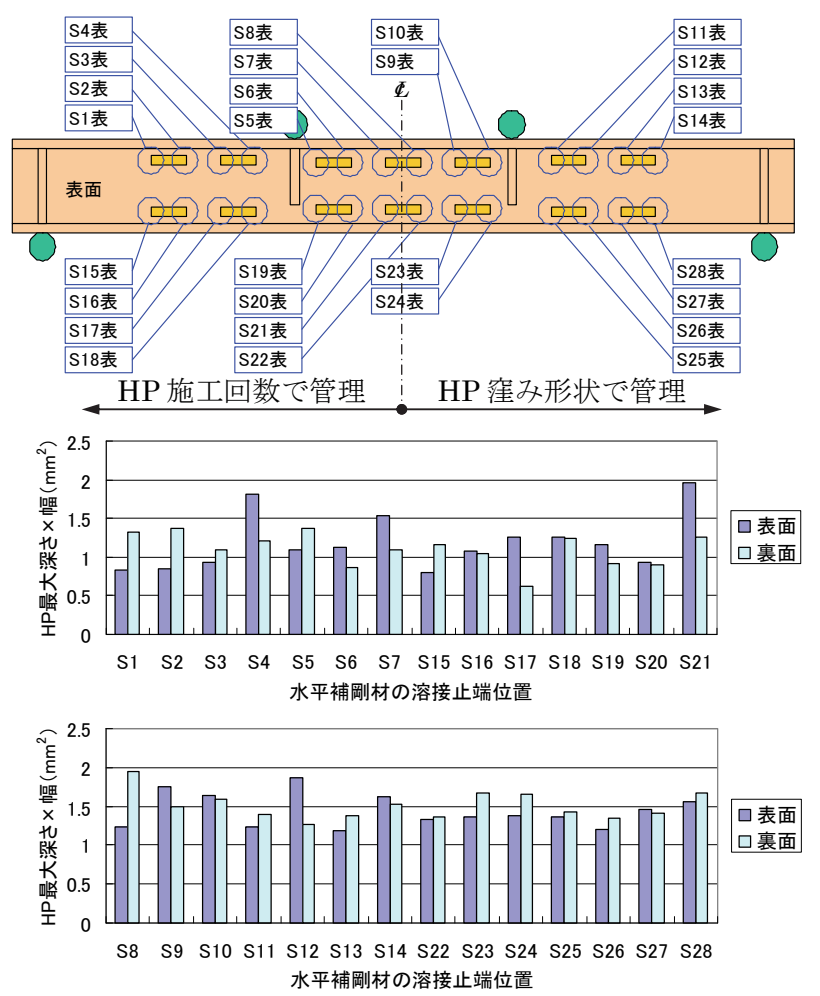

図-18 試験体 2 体目の各角回し溶接部の HP施工形状

表-3 各試験箇所に発生する公称作用応力範囲と各試験箇所が 各疲労等級を達成する載荷回数

\begin{tabular}{|c|c|c|c|c|}
\hline \multirow[t]{2}{*}{ 試験箇所 } & \multirow{2}{*}{$\begin{array}{l}\text { 公称作用応 } \\
\text { 力範囲(MPa) }\end{array}$} & \multicolumn{3}{|c|}{ 達成する載荷回数(千回) } \\
\hline & & E等級 & D等級 & C等級 \\
\hline S1,S14,S15,S28 & 74 & 2,519 & - & - \\
\hline S2,S13,S16,S27 & 91 & 1,380 & 2,695 & - \\
\hline S3,S12,S17,S26 & 99 & 1,063 & 2,076 & - \\
\hline S4,S11,S18,S25 & 115 & 669 & 1,307 & 2,553 \\
\hline $\mathrm{S} 5 \sim \mathrm{S} 10, \mathrm{~S} 19 \sim \mathrm{S} 24$ & 123 & 544 & 1,063 & 2,076 \\
\hline
\end{tabular}
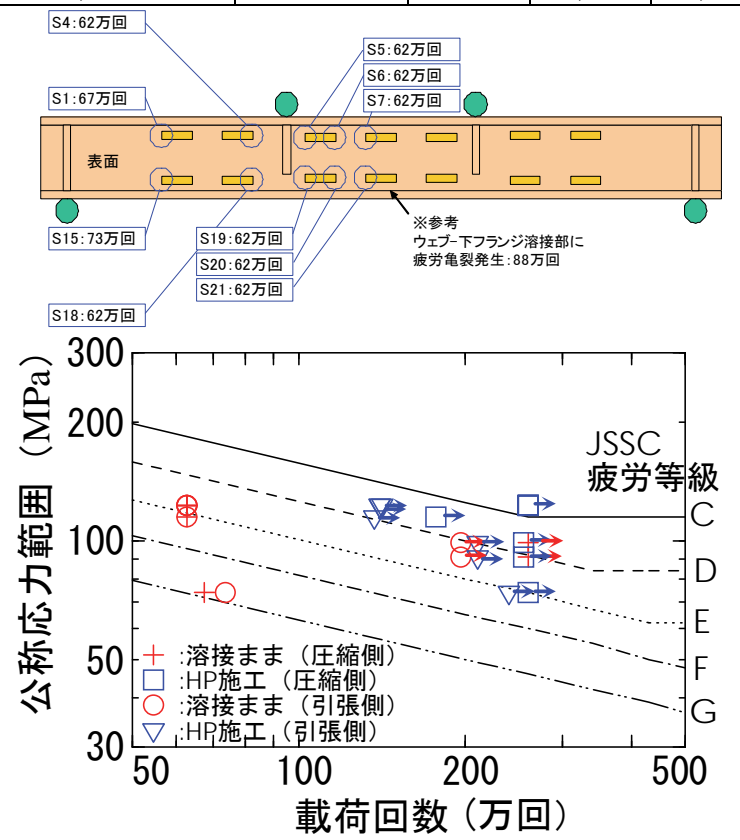

図-19 試験終了時の水平補岡材溶接部の亀裂発生状況および 載荷回数と公称応力範囲との関係（試験体 1 体目）

試験体 1 体目は, 溶接まま部における疲労亀裂進展に より HP 施工部が健全であるにもかかわらず試験続行が 
不可能となって終了した. そのため, 公称応力範囲が 123MPa および $115 \mathrm{MPa}$ の角回し溶接止端において疲労 強度 2 等級向上が確認できたものの, 公称応力範囲が 74MPa の角回し溶接止端において少なくとも疲労強度 1 等級向上を確認寸るに留まった，そこで，試験体 2 体目 は，公称応力範囲が 74MPa の角回し溶接止端において 疲労強度 2 等級向上確認を目的に, HP 施工管理レベル を試験体軸方向中央で分けるものの，全ての水平補剛材 角回し溶接部止端およびウェブとフランジとの溶接部の ウェブ側溶接止端に HP 施工後, 1 体目と同様な曲げ疲 労試験を実施した. 図-20には, 試験終了時の水平補剛 材溶接部の亀裂発生状況および載荷回数と公称応力範囲 との関係を示寸。

図-20 より, 角回し溶接部に疲労亀裂が発生した箇所 は，鋼桁に最大曲げモーメントが作用寸る区間のみであ ることが分かる. 載荷回数 197 万回で引張側角回し溶接 部 S19 に，233 万回で圧縮側角回し溶接部 S10 にそれぞ れルート亀裂が発生し, 載荷回数 362 万回で圧縮側角回 し溶接部 S8 の溶接止端に，385 万回で圧縮側角回し溶 接部 S5 の溶接止端にそれぞれ疲労亀裂が発生した. 試 験は 463 万回で終了した。写真-4(a),(b)および写真5(a),(b)には，試験箇所 S8 および S5における表面・裹面 の疲労亀裂発生状況をそれぞれ示す．写真-4(a),(b)およ び写真-5(a),(b)より，両試験箇所とも溶接止端に貫通亀 裂が発生していることが分かる．圧縮応力場にある試験 箇所 S8 および S5 に疲労亀裂が発生した理由は，写真4(b)および写真-5(b)から分かるように, S8 は溶接止端形 状が滑らかでなかったため，S5は HP 施工位置が溶接止 端部から $3 \mathrm{~mm}$ 程度離れている箇所があったため, 溶接 止端部の引張残留応力を HP 施工により完全に取り除く ことが出来なかったことに起因していると考えられる.

図-20 より，公称応力範囲 90〜127MPa において, HP 施工は C 等級を超え, HP 施工回数 2 回でも D 等級 (ル 一ト亀裂を除くと C 等級) を超えていることが分かる. また, 公称応力範囲 74MPa の最小応力部においても $\mathrm{E}$ 等級を超え, 面外ガセット $\mathrm{G}$ 等級より 2 等級向上して いることを確認した（前述した鋼析疲労試験 1 体目の溶 接ままの角回し溶接部の疲労強度等級は $\mathrm{G}$ 等級であ る).

なお，ウェブと下フランジとの溶接部から発生する疲 労亀裂は, 試験体 1 体目が載荷回数 88 万回に対し, 試 験体 2 体目が 152 万回で発生した.

\section{5. まとめ}

溶接止端近傍の母材をハンマー打撃することにより母 材に塑性変形を生じさせ，溶接止端に圧縮残留応力を導

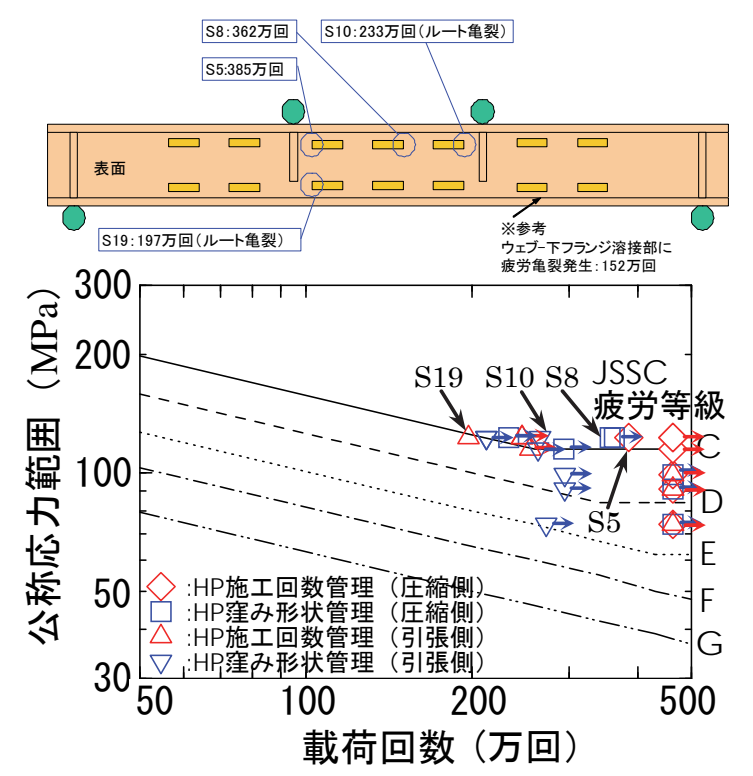

図-20 試験終了時の水平補剛材溶接部の亀裂発生状況および 載荷回数と公称応力範囲との関係（試験体 2 体目）

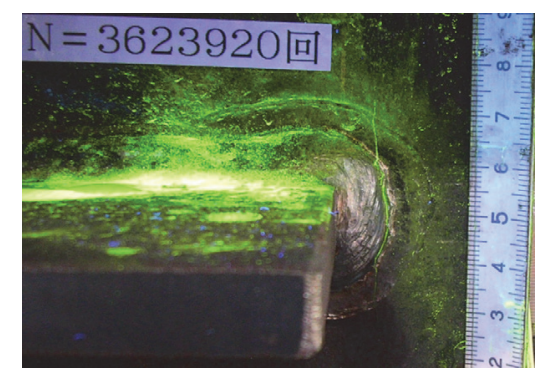

(a) 表面

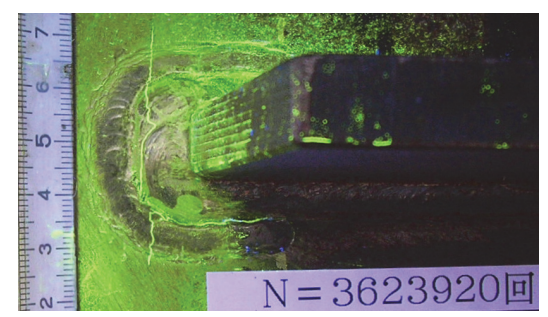

(b) 裏面

写真-4 試験箇所 S8 の疲労亀裂発生状況

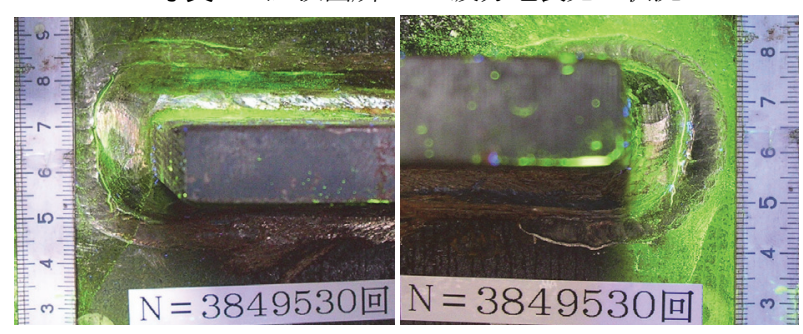

(a) 表面

(b) 裏面

写真-5 試験箇所 S5 の疲労亀裂発生状況

入する従来よりも施工の確実性を高めた新しいハンマー ピーニング技術を構築した. 本研究では, 溶接止端にお ける圧縮残留応力の大きさ, ハンマー打撃による塑性変 形量, および疲労強度の相互関係を明確にすることによ り, 少なくとも疲労強度 2 等級向上を達成するハンマー 
打撃痕形状の閾值を，溶接継手疲労試験により明確化し た.さらに，溶接継手疲労試験結果を実構造を模した鋼 桁曲げ疲労試験により検証した. 本研究で得られた主な 成果を以下にまとめる.

(i) 母材打撃ハンマーピーニングにより導入する圧縮残 留応力の大きさとハンマー打撃痕の窪み面積との間 には比例関係がある。

(ii) 母材打撃ハンマーピーニングによる疲労強度向上レ ベルは，ハンマー打撃痕の窪み面積により管理でき る.

(iii) SM490 材において，ハンマー打撃痕の窪み面積（幅 ×最大深さ）を $1 \mathrm{~mm}^{2}$ 以上とした場合，疲労強度 2 等級向上を保証するための打撃痕端部位置の閾值は， 溶接止端位置から $1 \mathrm{~mm}$ から $2 \mathrm{~mm}$ の間にある。

(iv) 実構造を模した鋼枌の曲げ疲労試験により，3 次元 的な応力場においても, 角回し溶接部の疲労強度が 母材打撃ハンマーピーニングにより 2 等級向上する ことを，公称応力範囲 74〜123MPa の範囲に関し実 証した.

なお，以上の(iii)の成果は手動による実験結果による ものであり，文献 13)に示すような装置による施工につ いては，別途の閾值や疲労強度の向上効果を検討寸る必 要がある。

\section{参考文献}

1) 石川敏之, 山田健太郎，柿市拓巳，李番：ICR 処理 による面外ガセット溶接継手に発生した疲労き裂の 寿命向上効果, 土木学会論文集 A, Vol.66, No.2, pp.264-272, 2010.6.

2) Anami, K., Miki, C., Tani, H. and Yamamoto, H. : Improving Fatigue Strength of Welded Joints by Hammer Peening and Tig-dressing, Structural Eng. JSCE, Vol. 17, No. 1, pp. 67-78, 2000.

3) Haagesen, P. J. and Maddox, S. J. : IIW Recommendations on Post Weld Improvement of Steel and Aluminium
Structures, IIW-XIII-1815-00, 2005.

4) 三木千壽，穴見健吾，谷英樹，杉本一朗：溶接止端 部改良による疲労強度向上法, 溶接学会論文集, 第 17 巻，第 1 号, pp.111-119, 1999.

5) 富永知徳, 三木千壽, 高橋健, 糟谷正, 森影康 : 低 温変態溶接材料を用いた既設鋼橋の疲労強度向上工 法の研究，土木学会論文集，Vol.758/I-67，pp.355-367, 2004.4.

6) 田井政行, 三木千壽, 鈴木啓悟 : ハンマーピーニン グ処理による面外ガセットの溶接止端部の疲労強度 改善，土木学会論文集 A, Vol.67, No.2, pp.396-409, 2011.

7) 野瀬哲郎, 島貫広志, 中島清孝, 鈴木環輝 : UIT に よる継手疲労強度向上機構, 溶接構造シンポジウム 講演論文集，pp. 219-222, 2006.

8) 原純哉, 下田太一郎, 出口貴則, 毛利雅志, 福岡哲 二，小汐啓介，加野大地：船体構造における超音波 ピーニングを用いた疲労強度改善に関する研究 第 1 報, 船舶海洋工学会講演会論文集, No. 10, pp. 599602, 2010.

9) 森猛, 島貫広志, 田中睦人, 宇佐美龍一：UIT を施 した面外がセット溶接継手の疲労強度に対する施工 時応力レベルと応力比の影響, 土木学会論文集 $\mathrm{A}$, Vol.67, No.2, pp.421-429, 2011.

10) (社) 日本鋼構造協会 : 鋼構造物の疲労設計指針・同解 説（2012 年改訂版），2012.6.

11) 森影康, 中西克佳, 伊木聡, 村上玩哉, 靹一：母材 打撃ハンマーピーニングによる継手疲労強度向上に 関する研究, 鋼構造年次論文報告集, Vol.21, No.114, 鋼構造協会, 2013.11.

12) 加藤健三 : 金属塑性加工学, pp.74-76, 丸善, 1971.

13) 中野隆, 鞆一：ICR 理ピーニングの自動化と打撃痕 管理，鋼構造年次論文報告集，Vol.21，No.113，鋼構 造協会, 2013.11.

14) 三木千壽, 杉本一朗, 鍛治秀樹, 根岸裕, 伊藤裕 一：既設鋼鉄道橋のフランジガセット取付け部の疲 労強度向上に関する研究, 土木学会論文集, No.584/I-42, pp.67-77, 1998.

(2014. 2. 21 受付)

\title{
STUDY ON IMPROVEMENT METHOD OF FATIGUE STRENGTH OF WELD JOINTS BY HAMMER PEENING ON BASE METAL
}

\author{
Katsuyoshi NAKANISHI, Yasushi MORIKAGE, Atsunori KAWABATA \\ and Hajime TOMO
}

This paper provides a new hammer peening technology which makes it possible to increase the fatigue strength of welding joints more certainly than before. This hammer peening procedure of applying plastic deformation only to the base material near weld toe enables compressive residual stress to be introduced into the weld toe. In this study, a method which calculate improvement volume of the fatigue strength from required plastic deformation volume after new hammer peening treatment is proposed, based on defining the interrelationships among the compressive residual stress at weld toe, the plastic deformation after peening treatment and the fatigue strength on the fatigue test results of welding joint specimens, and FE-Analysis results. Furthermore, we have performed the bending fatigue test of steel girder with welding joints to verify the validity of the fatigue test results of welding joint specimens. 